\title{
Financial Sanctions for breach of shareholders' duties
}

\author{
Jennifer Payne and Elizabeth Howell
}

\section{Introduction}

The focus in company law has traditionally been on shareholders' rights rather than shareholders' duties. While some forms of shareholders' duties have existed for many years, this is an issue that has come to greater prominence recently. This is due to a number of factors, including a growing recognition of the need to hold institutional investors accountable to their underlying investors, a trend that is evident in recent amendments to the Shareholder Rights Directive, ${ }^{1}$ and also a recognition that corporations, and by extension their shareholders, should be held more accountable for the effect they have on societal issues such as environmental matters. ${ }^{2}$ A discussion of shareholders' duties is therefore emerging in the rhetoric of academics, practitioners and regulators.

It is increasingly understood that any discussion of law on the books needs to be coupled with an analysis of the law in action. Issues of enforcement are therefore key to any consideration of the shape and nature of shareholders' duties. This paper will consider one particular aspect of such enforcement, namely the imposition of financial sanctions as and when shareholders' duties are breached. The term "financial sanctions" is not a term of art and requires some explanation. It is used here to mean sums required to be paid by a shareholder for breach of its duties qua shareholder. We include all forms of civil sanctions giving rise to such a payment, including damages for breach of contract and payments by way of compensation, but we do not include discussion of financial sanctions imposed following criminal proceedings (fines), as this has not, to date, been a significant means by which shareholder duties have been enforced.

Whether financial sanctions are imposed will depend on a number of factors. One of the key issues will be the nature of the breach and this depends in large part on how the duty arises. Parts 2 to 4 of this paper therefore consider the three different ways in which shareholders' duties can arise, namely by contractual agreement between the parties (shareholders' agreements) (Part 2); by way of the company's constitution, generally the articles of association (Part 3); and by imposition of law (Part 4). In each case the role and function of financial sanctions in enforcing the duties is considered. There are, however, other factors that will affect this issue which do not map exactly onto these categories, including the nature of the company, the identity of the claimant and defendant, whether claims also exist for other claimants, most notably the company, and the availability of other remedies. These issues are therefore discussed as relevant throughout the paper.

In Part 5 we draw together the threads of the arguments raised in the previous parts and we argue that financial sanctions can have the potential to play a valuable function with respect to enforcing shareholders' duties. That role will vary, however, depending on the way that the duty arises, as well as the wrongdoing in question. Specifically, where such duties are imposed via agreement, via the articles, or imposed by law in order to regulate the intra-shareholder relationship, then financial sanctions appear to have a relatively small role to play. This can be for a number of reasons, not least that it may be very difficult for parties to prove that a loss has been suffered due to a breach of duty, and that an alternative remedy may be preferable for the parties, such as the ability for a shareholder in a private company to exit the company at a fair price. In contrast, financial sanctions have the potential to play a greater role enforcing shareholders' duties in publicly traded companies, particularly where duties are imposed to

\footnotetext{
${ }^{1}$ Directive (EU) 2017/828 of the European Parliament and of the Council of 17 May 2017 amending Directive 2007/36/EC as regards the encouragement of long-term shareholder engagement.

${ }^{2}$ See e.g. C. Mayer, Firm Commitment (OUP, 2013).
} 
pursue broader societal goals, such as strengthening and supporting the European capital markets.

\section{Financial sanctions for breach of duties arising via a shareholders' agreement}

In simple terms, shareholders' agreements are governed by the ordinary rules of contract, and such agreements have the ability to play a valuable, if supplemental, role to a company's constitution. Such agreements can offer a number of benefits over the company's constitution, not least privacy, meaning it can be advantageous for the inclusion of more delicate matters, such as a firm's dividend policy, and the remuneration of directors. In general terms, in addition to the members agreeing to adhere to the agreement, the company itself may also be joined as a party, however jurisdictions can vary on this, and there are dangers, including that the company can risk being seen to be contracting out of its statutory powers. ${ }^{3}$

Although such agreements commonly include shareholders' rights, they can be less effective for the imposition of duties. First, under the doctrine of privity, only those shareholders who are the parties to the contract are bound, and so it will not automatically bind new members, or transferees. Although incoming members can be required to execute a deed of adherence to the agreement, this quickly becomes impractical in companies where the identity of the members is frequently changing. ${ }^{4}$ Accordingly, shareholders agreements are only of limited use in larger companies. Next, as shareholders' agreements adhere to classical contractual law principles; the consent of all the parties will be necessary to form, and vary, the contract and to agree to the creation, and alteration, of rights and the imposition of duties. This means it may not be useful for the imposition of duties in the first place as a member could simply refuse to enter the contract. ${ }^{5}$ As a result, shareholders' agreements have their greatest relevance in practice for small companies with a stable shareholder base, and in situations where the contractual rights and obligations are those to which the members wish to subscribe.

\section{(i) Enforcement: Overview}

At the enforcement level, in general terms, contractual obligations are enforceable by the parties as of right. Claimants seeking to enforce a breach of duty will also not be constrained by the additional rules of company law, which can, for instance, require that claims be brought by members in their capacity as members (see further Part 3 below). Accordingly, in principle, shareholders, and/or the company itself (if a party, and is not seen to be fettering its powers) can bring a claim, or be held to account, for breaches of duty arising from a shareholders' agreement.

Before considering contractual enforcement, it should first be observed, however, that a shareholders' agreement may provide for its own resolution mechanisms. Especially keeping in mind the private nature of a shareholders' agreement, the terms may specify, for instance, that any dispute be escalated to an independent third party for resolution, or the agreement may require that disputes be referred to binding arbitration. Alternative dispute resolution

\footnotetext{
${ }^{3}$ E.g. Russell v Northern Bank Development Corp Ltd [1992] 1 WLR 588 HL. Severance may be possible, but, if not, the validity of the whole contract could be jeopardised, see Eilis Ferran, 'The Decision of the House of Lords in Russell v. Northern Bank Development Corporation Limited' (1994) 53 Cambridge Law Journal 343.

${ }^{4}$ It can also be tricky to make adherence arrangements completely watertight, see Gower Principles of Modern Company Law, P. Davies and S. Worthington eds, $10^{\text {th }}$ edn, (2016, Sweet \& Maxwell), chapter 19.

5 Jennifer Payne, "Contractual Aspects of Shareholders' Duties" in H. Birkmose (ed), Shareholders' Duties (Kluwer, 2017), chapter 6.
} 
procedures can offer a number of benefits, especially keeping in mind the costs and related downsides of litigation, and arbitration proceedings will also have the advantage of being confidential. $^{6}$

Aside from this, in principle, a range of contractual remedies is available, the aim being (broadly) to protect the injured party's right to contractual performance. In general terms, contractual remedies can be divided into three broad categories: compensatory financial damages (in practice the most common remedy on a breach of contract claim); noncompensatory financial remedies (where other aims, such as preventing a defendant profiting from a breach, are relevant); and specific remedies (which impose duties on the contractbreaker, such as providing that a sum is payable on breach of contract). ${ }^{7}$ With respect to this third category, granting an equitable remedy (such as an award of specific performance or an injunction) may also be preferable to a member, rather than a damages award. Such remedies are attractive as they can compel a shareholder to comply with the agreement and/or to perform or refrain from specific acts. For example, in Puddephatt $v$ Leith, an undertaking by a member to vote their shares in a particular way, as directed by another person, was enforceable by a mandatory injunction. ${ }^{8}$ In many civilian legal systems (and in Scotland), some specific remedies may be relatively easily accessible in principle: for instance, a plaintiff is prima facie entitled to an award of specific performance. ${ }^{9}$ In contrast, however, the English courts have been relatively reluctant to make such awards.

\section{(ii) Damages}

Turning to financial remedies, a breach of duty under a shareholders' agreement can give rise to a compensatory financial damages award. Nonetheless a shareholder claiming this remedy faces a number of hurdles. First, a common law claim for contractual damages will confine a claimant to recovering the actual loss suffered as a result of the breach, and the loss suffered by a breach of duty may be tricky to prove, or to quantify. Such issues will depend on the nature of the breach in question, but, for instance, it could be difficult to prove or quantify the loss suffered by the breach of a duty of disclosure. Next, shareholders may be barred from claiming damages if the loss flows to the company (the 'reflective loss' principle). Broadly, in most jurisdictions, the basic principle is that, where the company suffers loss caused by a breach of duty owed to it, only the company may sue in respect of that loss. No action lies with the shareholder where the shareholder's loss merely reflects that suffered by the company. ${ }^{10}$ Exceptions do exist, so for instance where, by reason of the wrong done to it, it is impossible for the company to sue, then a member may be able to recover personal losses arising from the wrongdoing. ${ }^{11}$ Further, in some jurisdictions, including the Netherlands and England, a member can have an independent cause of action if a separate legal duty towards the shareholder has been violated. ${ }^{12}$ Nonetheless, in practice, it is not necessarily easy to distinguish between

\footnotetext{
${ }^{6}$ E.g. Fulham Football Club (1987) Ltd v Richards \& Another [2011] EWCA Civ 855.
}

${ }^{7}$ See further Ewan McKendrick, Contract Law: Text, Cases and Materials (OUP ed, 7th edn, 2016); Janet O'Sullivan, The Law of Contract (OUP ed, 7th edn, 2016).

${ }^{8}$ [1916] 1 Ch 200.

${ }^{9}$ Note, however, that there is considerable overlap between the situations in which different jurisdictions would refuse such an order (i.e. including where performance of the contract would expose a defendant to severe hardship).

${ }^{10}$ E.g. Johnson v Gove Wood and Co [2002] 2 AC 1. A number of rationales are put forward for the rule, including the prevention of double recovery and the protection of creditors.

${ }^{11}$ Giles v Rhind [2002] EWCA Civ 1428.

${ }^{12}$ See Bas J. de Jong, 'Shareholders' Claims for Reflective Loss: A Comparative Legal Analysis' (2013) 14 EBOR 97. 
reflective and independent losses. Taken together, although it has been stated that there is there is 'surprisingly little authority' on shareholders' agreements and the breach thereof, ${ }^{13}$ when one bears in mind these obstacles (and that the outcome of any arbitration procedures will be confidential) this may be less remarkable than at first glance.

With this in mind, the availability of an alternative, if exceptional, form of compensatory damages is worthy of consideration. This has been considered recently with respect to breaches of non-compete obligations in a shareholders' agreement in the English Court of Appeal case of Morris-Garner v One Step (Support) Ltd. ${ }^{14}$ Here, the seller of shares in a joint venture company deliberately breached non-compete and non-solicitation obligations covertly. It was difficult for the claimants to identify the financial loss it had suffered by the defendants' breaches, and the damages awarded were assessed not on the normal measure, but as a sum it would have been reasonable for the party in breach to pay for the hypothetical release of the covenants immediately before the breach (sometimes referred to as 'Wrotham Park' damages) ${ }^{15}$ Undoubtedly the greater availability of such awards could help tackle some of the difficulties parties have when faced with the 'normal' contractual basis. Nonetheless, this approach has not been universally welcomed, and the orthodox view is that such awards are to be made only exceptionally. ${ }^{16}$

\section{(iii) Agreed Damages Clauses}

In light of these various issues, one alternative is to insert an agreed damages clause into the agreement providing that a specific amount is payable in the case of breach. ${ }^{17}$ Such a clause requires the defaulting party to pay a fixed sum regardless of the loss that is actually suffered. These types of terms can provide benefits to both parties: they can avoid court involvement and can enable parties to set out in advance the amount payable in the event of a breach. Nonetheless, under all major systems of law, there is a long-standing rule enabling courts to strike down terms that are, in fact, punitive penalties. In England, the retention of this penalty clause jurisdiction has been a topic of much debate, not least because in the case of sophisticated market participants of roughly equal bargaining power, there are powerful arguments to the effect that the principle of freedom of contract should prevail. ${ }^{18}$ Such parties are generally capable of protecting their own interests, and it should not be possible for them to be relieved of their obligations simply because an agreement turns out to be a bad bargain. ${ }^{19}$

\footnotetext{
${ }^{13}$ Robin Hollington, Hollington on Shareholders' Rights (8th edn, Sweet \& Maxwell 2016), chapter 3.

${ }^{14}$ Morris-Garner v One Step (Support) Ltd [2016] EWCA Civ 180.

${ }^{15}$ See Wrotham Park Estate Co v Parkside Homes Ltd [1974] 1 WLR 798 where a reasonable sum was awarded when the defendant had breached his duty to the claimant by building houses in breach of a restrictive covenant.

${ }^{16}$ E.g. although in the context of breach of duties of confidence under contracts of employment, the High Court in Marathon Asset Management LLP v Seddon [2017] EWHC 300 (Comm) cast doubt on the availability of Wrotham Park damages. Further, much will depend on whether the approach in One-Step finds favour on its appeal to the Supreme Court.

17 The insertion of such clauses is common in many jurisdictions. For instance, in Denmark, although the Danish Company Act 2010 provides that shareholders' agreements are neither binding on the company nor on decisions taken by the general assembly, agreed damages clauses tend to be inserted in shareholders' agreements to prevent or to remedy breach.

${ }^{18}$ E.g. Sarah Worthington, 'Common Law Values: The Role of Party Autonomy in Private Law' in A Robertson and M Tilbury (eds), The Common Law of Obligations: Divergence and Unity (Hart Publishing, 2015), Ch 14.

${ }^{19}$ With respect to concerns that such clauses could adversely affect consumer contracts, specific regulations are in place (via unfair terms provisions) to protect consumers.
} 
The recent English Supreme Court decision of Cavendish Square Holdings BV v El Makdessi ${ }^{20}$ is therefore pertinent for consideration for two reasons: first, to the disappointment of many commentators, the court refused to abolish the penalty clause jurisdiction; but secondly, it identified that financial compensation may not necessarily be the only legitimate interest an innocent party has in including such a clause. ${ }^{21}$ In general terms, the case concerned a clause in a share sale agreement designed to protect goodwill in the company, where, if the seller breached the non-compete restrictive covenants, the seller lost the right to receive the final two instalments of the price (approximately 44 million dollars). The seller breached this duty by competing with the business, the purchaser withheld these payments, and the seller argued this was a penalty. The Court of Appeal held the clause to be a penalty and unenforceable, largely due to the fact that, according to the court, the payment strayed beyond the function of compensation and entered the territory of deterrence. ${ }^{22}$ In Clarke LJ's view, the agreement prescribed a type of double jeopardy for the seller: the buyer would have remedies under the clause for breach of the restrictive covenant, and the seller would still remain liable to the company. ${ }^{23}$

The Supreme Court, however, held that the clause was not a penalty. In particular, the court stated that there was no simple distinction between clauses focused on compensation, and those focused on deterrence, stating that 'a deterrent provision in a contract is simply one species of provision designed to influence the conduct of the party potentially affected'. ${ }^{24}$ Further, although recognising that in straightforward cases, the innocent party's interests will rarely extend beyond compensation, it acknowledged that this was not necessarily a party's only legitimate interest, and that such clauses would only be struck down where 'unconscionable' or 'extravagant'. ${ }^{25}$

Regardless of one's stance on whether or not the penalty jurisdiction serves a valuable purpose, the Supreme Court's focus on the issues of compensation and deterrence is significant. Although an innocent party should not have an interest in punishing a contract-breaker, a carefully drafted clause should be, in principle, capable of both operating as a deterrent (in an attempt to secure performance), and also providing a means of obtaining compensation in the event of breach. Perhaps this is all the more vital in the arena of company law, given that shareholders could otherwise be barred from recovering damages due to the reflective loss principle.

\section{(iv) Enforcement: The Company}

The enforcement situation is more complex where the company is a party to the agreement. First, where the contract contains terms that fetter the company's exercise of its statutory

\footnotetext{
${ }^{20}$ [2015] UKSC 67.

${ }^{21}$ Jonathan Morgan, 'The Penalty Clause Doctrine: Unlovable but Untouchable' (2016) 75 Cambridge Law Journal 11.

22 The traditional view was that clauses designed to deter breach were penal and unenforceable, see Dunlop Pneumatic Tyre Co Ltd v New Garage and Motor Co Ltd [1915] AC 79.
}

\footnotetext{
${ }^{23}$ Accordingly, as the company had suffered a small loss due, the reflective loss principle was engaged and the buyer was unable to recover, El Makdessi v Cavendish Square Holdings BV and Another [2013] EWCA Civ 1539 at paras 106, 120-121. See also Janet O'Sullivan, 'Lost on Penalties' (2014) 73 Cambridge Law Journal 480.

${ }^{24}$ Per Lords Sumption and Neuberger at para 31.

${ }^{25}$ Ibid paras 31-32. Interestingly, the Supreme Court also considered that in principle (in the absence of reflective loss issues) a claim for common law damages could also remain open to the buyer (if they had suffered any loss), and left open whether or not the existence of such a contractual clause would abate any such loss recoverable by the party, see paras 76,277 .
} 
powers, such terms will be unenforceable (although these may be enforceable against the shareholders if the company's obligation is severable) ${ }^{26}$ But this limitation does not necessarily mean that, for instance, a company cannot bring a claim for breach, or that a claim cannot be brought against the company for breach of a prior contract. Nevertheless, even if damages are available in principle, in line with earlier observations, these may prove difficult to quantify. For example, in Cullen Investments $v$ Brown and Others, ${ }^{27}$ the company, who was party to a joint venture agreement, was in principle entitled to an award for damages arising from the other party's breach of their contractual duty of disclosure. Barling J commented that this may be of little more than academic interest, however, as it was not clear the company had suffered any loss due to the breach. Although alternative bases, including a non-compensatory disgorgement of profits, was considered, there was an absence of detailed submissions by the parties. Further, given that the company succeeded on its primary case of breach of directors' duties, the likely outcome was an account of profits that would render the contractual claim otiose.

Drawing this section together, it is clear that financial sanctions for breach of duty are available to shareholders as a matter of general contract law. In practice, however, it can be difficult for parties to prove a loss has been suffered due to such a breach; and shareholders may also be barred from bringing a claim due to the reflective loss principle. Although alternative bases for calculating damages exist that can hold a shareholder accountable (such as Wrotham Park damages), these remain controversial, and have had, until recently, relatively limited applicability to breaches of shareholder agreements. Rather, the alternative of including an agreed damages clause providing for a quantified sum payable on a breach of duty, may both offer more protection to the parties. Such a clause can seek to secure performance in the first place, and provide a privately agreed financial sanction in the event of breach. ${ }^{28}$

\section{Financial sanctions for breach of duties arising via a breach of the articles}

(i) Overview

In addition to shareholders' agreements, shareholders' duties can also be created from the company's constitution, usually via the articles of association. To some extent the constitution is a type of contract; so, for instance, in England, section 33 of the Companies Act 2006 deems the constitution to be a contract between the company and each of the members: a 'multi-party' contract. This means, in line with Part 2 above, the provisions are, in theory, enforceable by one party against another and can be engaged where there is a breach or threatened breach of duty. At the same time, it is also commonplace to observe that the articles differ from a conventional contract; in particular, as the constitution is a public document (unlike a shareholders' agreement), the courts consider that contract law should apply with qualifications. ${ }^{29}$ For example, to ensure the protection of third parties who rely on the publicly available documents, the English courts have held they have no jurisdiction to rectify the articles. ${ }^{30}$

\footnotetext{
${ }^{26}$ Russell v Northern Bank Development Corp Ltd [1992] 1 WLR 588.

27 [2017] EWHC 1586 (Ch).

${ }^{28}$ See Sarah Worthington, 'Common Law Values: The Role of Party Autonomy in Private Law' in A Robertson and M Tilbury (eds), The Common Law of Obligations: Divergence and Unity (Hart Publishing, 2015), Ch 14 who observes that contract law is exclusively concerned with agreed 'private financial sanctions' including agreed remedies.

${ }^{29}$ This is also a requirement of EU law, see Directive 2009/101/EC, art 2(a).

${ }^{30}$ E.g. Scott v Frank F Scott (London) Ltd [1940] Ch 794 CA.
} 
From the point of view of imposing duties on members, unlike a shareholders' agreement, the articles automatically bind new members to the company. This helpfully circumvents the obstacles observed in trying to seek the adherence of new shareholders joining the company, and suggests that the articles may be a useful vehicle for the imposition of duties. Yet, on the other hand, as the articles can generally be altered by majority vote, it may be tricky to impose a new duty in the face of opposition from the majority. ${ }^{31}$ Hence, although duties can be imposed on shareholders via the articles, it is not that common an occurrence in practice.

\section{(ii) Enforcement: Overview}

At the enforcement stage (and in comparison with obligations in a shareholders' agreement that are enforceable as of right) there are a number of challenges for aggrieved members. Specifically, there are an 'odd medley' of company law principles that can hamper the bringing of a claim under the articles. ${ }^{32}$ For instance, English courts require members to bring actions in their capacity as a member (the 'qua member' rule) and not in some other capacity. ${ }^{33}$ Further, if the court regards the wrong in question as merely an internal irregularity, capable of simple ratification by the majority, no personal remedy will be available for the member. ${ }^{34}$

With respect to the remedies available for breach of the articles, most company law remedies are discretionary, and, in England, the imposition of a financial sanction for breach of the articles is rare. In part this is due to the fact that, prior to legislative intervention in the 1980s, it was not possible for shareholders to claim damages against a company for breach of the statutory contract. ${ }^{35}$ The rationale for this particular restriction was never entirely clear, and the current law now provides that being a member does not preclude a claim for damages. ${ }^{36}$ Aside from this, the rarity of actions resulting in a financial remedy is also likely due to issues considered in Part 2; a shareholder may struggle to prove the loss suffered by the breach; and/or the company may be regarded as the proper claimant. Accordingly, in practice the alternative of an unfair prejudice petition may provide a more straightforward avenue for an aggrieved member faced with a breach of duty than attempting to bring a claim for breach of the articles. ${ }^{37}$

(iii) Who Can Enforce the Statutory Contract?

In line with Part 2, the starting point is that it is the parties to the contract who are capable of bringing a claim, ${ }^{38}$ meaning the company can enforce the articles against the members, the members can enforce inter se, and the members can enforce against the company. The first two categories are relatively straightforward and, although not resulting in a financial sanction, there are some illustrations concerning enforcement for breaches of duty under the articles. For

\footnotetext{
${ }^{31}$ See further J Payne, “Contractual Aspects of Shareholders' Duties”, supra n 5, chapter 6.

${ }^{32}$ Sealy and Worthington, Text, Cases, and Materials in Company Law (11th edn, OUP 2016) chapter 4.

${ }^{33}$ Hickman v Kent or Romney Marsh Sheep-Breeders' Association [1915] 1 Ch 881. In practice this principle can often be worked around but it nonetheless remains an enforcement constraint.

${ }^{34}$ MacDougall v Gardiner (1875) 1 Ch D 13; cf Pender v Lushington (1877) 1 Ch D 13.

${ }^{35}$ Houldsworth v City of Glasgow Bank (1880) 5 App Cas 317, HL; Re Addlestone Linoleum Co (1887) 37 Ch D 191, CA. ${ }^{36}$ Sealy and Worthington, supra n 32, chapter 4. Change occurred via Companies Act 1985, s 111A, see
now Companies Act 2006, section 655.

${ }^{37}$ See e.g. Law Commission, Shareholder Remedies (Report No 246, 1997), part 7.

${ }^{38}$ Note that third parties (certainly in England) have no rights to enforce the articles, see The Contracts (Rights of Third Parties) Act 1999, s 6(2).
} 
example, the English case of Hickman v Kent or Romney Marsh Sheep-Breeders' Association ${ }^{39}$ concerned a breach of a member's obligation to submit disputes to arbitration. The company could enforce the statutory contract on the member, and a stay of legal proceedings was awarded. Equally, with respect to a member enforcing the articles inter se, in Rayfield $v$ Hands ${ }^{40}$ the articles provided that where a member wished to transfer his shares, the member could oblige the directors (who were also members) to take the shares. The court allowed the member to enforce the duty-imposing provision, ordering the purchase of the shares.

The third category of enforcement, namely against the company, is the most problematic, although more tangentially related to the issue of shareholders' duties. Nevertheless, the challenges facing members in such situations may also have a knock-on impact with respect to the likelihood of a member trying to enforce the statutory contract in other situations. In general terms, the English courts take a particularly restrictive approach to claims brought against the company. This is linked to earlier observations that breach of such obligations may be held to relate merely to an internal irregularity on the company's part, rather than the infringement of a personal right. More generally, even if a claim is actionable, the likely (or preferable) remedy may be a specific remedy such as an injunction, rather than the imposition of a financial sanction. ${ }^{41}$

An alternative approach to tackling the question of enforcement under the articles has been mooted. This would involve a default rule providing that all obligations are capable of enforcement contractually by members, both against other members and the company (unless the breach was trivial or the remedy fruitless; or unless the contrary was stated in the constitution). ${ }^{42}$ Damages would then be an available remedy if the shareholder personally (as opposed to the company) suffered loss by the breach. This proposition comes with its own issues, not least practical concerns, including likely litigation levels, and the impact it could have on the length and complexity of a company's articles. Nevertheless, it has much to commend it, including enabling financial sanctions (and their threat) to potentially play a bigger role, in the event of a breach of duty arising. Indeed, in England, the proposition was strongly supported as part of the proposed revisions to the companies legislation, but was not embraced in the 2006 Act.

Taken together, what is evident is that although the constitution can be used as a vehicle for imposing duties on members, this occurs only rarely in practice. Next, the various stumbling blocks a member must overcome in order to bring a successful claim means actions for breach of the articles are relatively uncommon. Finally, and in line with Part 2, aggrieved shareholders seeking a financial remedy may struggle to prove and quantify the loss suffered by a breach.

\section{Financial sanctions for breach of duties imposed by law}

The law has intervened in the shareholders' bargain and introduced various duties upon the shareholders. These duties may be imposed by statute, case law, regulation and even, potentially, as a result of soft law norms. There are various reasons why the law may seek to impose duties on shareholders, ${ }^{43}$ but the most common are where the intervention is designed

\footnotetext{
${ }^{39}$ [1915] 1 Ch 881.

${ }^{40}$ Rayfield v Hands [1960] Ch.1.

${ }^{41}$ See e.g. Pender v Lushington (1877) 1 Ch. D. 13.

${ }^{42}$ K. W. Wedderburn, 'Shareholders' Rights and the Rule in Foss v. Harbottle' (1957) 15 Cambridge Law Journal 194; Company Law Review Steering Group, Modern Company Law for a Competitive Economy: Final Report (2001), chapter 7.

${ }^{43}$ See Jennifer Payne, “Contractual Aspects of Shareholders’ Duties”, supra n 5, §6.05.
} 
to provide minority shareholders with protection from the majority, i.e. to regulate the intrashareholder relationship, and where the intervention is designed to protect other stakeholders, whether this is the employees, creditors or investors in the capital markets more generally. An example of the first is the obligation imposed on shareholders by the English courts to vote bona fide in the interests of the company as a whole when altering the articles of association. ${ }^{44}$ Some jurisdictions go further and impose a duty of loyalty on shareholders. ${ }^{45}$ An example of the second is the duty imposed on institutional shareholders by the revised Shareholder Rights Directive to develop a policy on shareholder engagement and to disclose that policy. ${ }^{46} \mathrm{This}$ is intended to tackle concerns about short termism in the financial markets and concerns about a lack of institutional shareholder engagement more generally, and thus to benefit investors generally.

Given that the law creates these duties, the nature of the remedy when the duty is breached is also determined by the law, rather than by the agreement of the parties. The law does not always make financial sanctions available for breach. Whether they are depends on a number of factors, including the nature of the wrong, the identity of the defendant and, ultimately, on what the remedy is intended to achieve.

\section{Intra-shareholder duties}

The structure of companies varies enormously, on a spectrum from widely dispersed shareholding structures to single person companies. It is very common, however, to see structures in which one shareholder, or a small group of shareholders, exercises control. Most jurisdictions support majority control, allowing a specified percentage of the shareholders short of 100 per cent to pass resolutions and to act as and for the company. This is necessary for the effective operation of companies, but it leaves the minority exposed to the risk of abuse. The law will not step in to support minority shareholders in all scenarios, however. The fact that the minority is unhappy with the business policy determined by the majority is unlikely to prompt intervention, but other actions, for example the expropriation of the minority's shares, may do so.

To understand the remedies made available in this context, it is necessary to understand the reason for the law's intervention. It is notable that in many jurisdictions the law will intervene in the bargain between shareholders in order to provide minority shareholders with remedies in the event that they are treated unfairly by the majority. The concept of unfairness is one which requires some clarification if it is to be meaningfully applied in this context. The justification for the law's intervention rests on the fact that the shareholders strike a bargain when they enter a company, sometimes an explicit one via a shareholders' agreement, but more often the bargain is based on the company's constitution. As discussed in part 3, this is a peculiar form of contract, not least because it can be amended without a minority shareholder's consent. For shareholders in a private company, without a ready market for their shares, this means that they may be effectively locked into a company that is materially different to the one in which they acquired shares. If a legal system wishes to incentivise investors to continue to take minority positions then some form of intervention is likely to be needed. This may take the form of rights, but can also involve duties imposed on the majority.

\footnotetext{
${ }^{44}$ Allen v Gold Reefs of West Africa Ltd [1900] 1 Ch 656; Citco Banking Corp NV v Pusser's Ltd [2007] UKPC 13; Re Charterhouse Capital Ltd [2015] EWCA Civ 536.

${ }^{45}$ For discussion see A. Cahn, "The Shareholders' Fiduciary Duty in German Company Law" in H. Birkmose (ed) Shareholders' Duties (2017, Kluwer).

${ }^{46}$ Directive (EU) 2017/828 of the European Parliament and of the Council of 17 May 2017 amending Directive 2007/36/EC as regards the encouragement of long-term shareholder engagement, Art 1(3) inserting new Art 3(g) into Directive 2007/36/EC.
} 
Unfair treatment of the minority often arises from decisions taken in the general meeting and so attention in this area can provide the minority with protection. The law generally provides rules to govern this issue, such as determining the size of the majority required to pass certain decisions. This may also include setting out certain decisions that the majority are simply not permitted to take, such as increasing the size of a shareholder's investment in the company without their consent ${ }^{47}$ or specifying circumstances in which controllers are excluded from voting on particular issues. The law may go further, however, and impose duties on shareholders regarding how they may exercise their power to pass shareholder resolutions. For example, in English law the courts have implied a requirement that shareholders act in a particular way when voting to alter the articles of the company. In Allen $v$ Gold Reefs of West Africa $\mathrm{Ltd}^{48}$ the Court of Appeal held that the power to alter the articles must be exercised "not only in the manner required by law, but also bona fide for the benefit of the company as a whole, and must not be exceeded. These conditions are always implied, and are seldom, if ever expressed." 49

If the majority breach this duty, it is for the minority to bring a claim, not a regulator. If the claim succeeds, the remedy provided is not a payment to the shareholder, but (potentially) a reversal of the majority decision. In voting to amend the articles, the shareholders are, collectively, acting as the company. If the majority act improperly (however that is defined) ${ }^{50}$ in voting to alter the articles, the principle set out in Allen v Gold Reefs of West Africa Ltd enables a minority shareholder to assert that the amendment is improper and should be set aside. Effectively, the claim is that the appropriate procedure has not been followed, and the amendment is thus invalid. Consequently, it is unsurprising that, if the court agrees that the decision is improperly taken, the remedy is to nullify the decision rather than to award a financial remedy. These cases effectively allow the minority a general right of appeal regarding the validity of shareholder resolutions. It will then be for the court to determine how interventionist it is prepared to be.

One form of protection that the law can provide to the minority is therefore to ensure that the majority sticks to the rules provided by the law, whether those rules are explicitly or implicitly expressed. This addresses the point that the rules governing the company may be changed after the minority shareholder enters the company, ie the bargain entered into by the shareholder may change, but only in specified ways that either the shareholder can determine in advance or in circumstances where the shareholder can appeal to the court regarding the fairness of the alteration ex post.

Another form of protection is to provide the minority shareholder with a more direct form of redress. In particular, as set out above, the concern for the minority shareholder in a private company may be being locked in to a company which differs substantially from that which the shareholder joined. Some jurisdictions therefore provide the minority with appraisal rights, that is the right to exit the company at a fair price if certain decisions with which they disagree are taken by the majority. Crucially, they comprise not simply the right to exit the company, but to exit at a fair price, and as such they may also provide benefit to shareholders in a listed company. In English law, appraisal rights following specific decisions are relatively

\footnotetext{
${ }^{47}$ Companies Act 2006, s 25(1). Similar provisions are found in other jurisdictions, e.g. AktG $\S 180$ in Germany.

${ }^{48}$ [1900] 1 Ch 656.

${ }^{49}$ Ibid, 671. See eg Citco Banking Corp NV v Pusser's Ltd [2007] UKPC 13; Re Charterhouse Capital Ltd [2015] EWCA Civ 536.

${ }^{50}$ The "best interests of the company" test is unclear and has been the subject of much judicial and academic discussion. For discussion see Gower Principles of Modern Company Law, supra n 4, 19-4$19-11$.
} 
uncommon, reflecting the view that their use can place potentially significant hurdles in the path of the decisions that trigger those rights. ${ }^{51}$ However, minority shareholders have a more general remedy under English law that can be utilised in this scenario, namely an unfair prejudice petition under sections 994-996 Companies Act 2006. The most common remedy provided is a buy-out of a successful petitioner's shares at a fair price. ${ }^{52}$ This can be a useful alternative to a claim that the decision-making contained a procedural defect. The prospect of a more direct remedy may also be attractive. The courts have a wide remedial discretion to "make such order as it thinks fit for giving relief in respect of the matters complained of" ${ }^{53}$ and so are not limited to the buy-out order.

Financial compensation is one possibility, but this poses a number of difficulties. First, it would be necessary for the petitioning shareholder to demonstrate that financial compensation is the appropriate remedy. In general, these cases involve small quasi-partnership companies and the fact of disagreement and litigation between the parties makes it unlikely that they will be able to work together in the future. ${ }^{54} \mathrm{~A}$ remedy which enables a 'clean break', is often the most appropriate outcome. Where the petitioner does request payment of some kind, it will generally be for specific unpaid sums, such as dividends that have not been declared in favour of the petitioning shareholder ${ }^{55}$ Second, the shareholder would presumably need to demonstrate that the breach of duty had caused them loss, something which may not be straightforward, as discussed in part 2 above. Third, any such order raises the possibility that the payment may fall foul of the reflective loss principle set out in part 2. The relevance of the reflective loss principle to unfair prejudice claims has not been discussed often by the English courts, in part because financial compensation is rarely a remedy sought by petitioning shareholders. ${ }^{56}$ This principle is potentially problematic for petitioning shareholders in the scenario in which the shareholder is basing the petition on a breach of the articles, or a breach of the duty to pass a shareholders' resolution in the correct manner, since this is a wrong both to the company and to the shareholder. As a minimum, any court considering the payment of financial compensation would need to ensure that there is no possibility of double recovery by the shareholder.

In summary, financial sanctions appear to have relatively little part to play in enforcing any of the intra-shareholder duties examined in this section. Instead, the law appears to focus on providing more pragmatic remedies, whether that is the reversal of an improperly taken majority decision, or facilitating the exit of the minority from the company at a fair price.

\footnotetext{
${ }^{51}$ See e.g. Insolvency Act 1986 ss 110-111 (triggered by a decision to reorganise the company). The sellout rights held by minority shareholders following the acquisition of a controlling block by a bidder (Companies Act 2006, s 983) is similar, but is triggered by a control shift rather than a corporate decision.

${ }^{52}$ See Re Bird Precision Bellows Ltd [1984] Ch 419.

${ }^{53}$ Companies Act 2006, s 996(1).

${ }^{54}$ It is possible for shareholders in publicly traded companies to petition under ss 994-996 Companies Act 2206, but such claims are rare, in part because they have the ability to exit the company without the aid of the court, by selling their shares on the market, see e.g. Re Astec (BSR) plc [1998] 2 BCLC 556.

${ }^{55}$ Claims for unpaid dividends will fail, absent any special circumstances as shareholders generally have no legitimate expectations to receive them. However, a claim may succeed where the petitioner can demonstrate some special arrangement, such as an agreement that the profits of the company would be taken out in a particular way (e.g. by the payment of dividends) that was subsequently breached: $R e$ Sam Weller \& Sons Ltd [1990] BCLC 80; Re J \& S Insurance \& Financial Consultants Ltd [2014] EWHC 2206 (Ch).

56 The issue did arise in Atlasview Ltd v Brightview Ltd [2004] EWHC 1056, where the judge felt that the reflective loss principle did not apply, but there are reasons to doubt the judge's decision in that case, see Jennifer Payne, "Sections 459-461 Companies Act 1985: The Future of Shareholder Protection" (2005) Cambridge Law Journal 647, 667-674.
} 


\section{(ii) Duties to other stakeholders}

By way of contrast, financial penalties seem to have a potentially more significant role where the duties are intended to benefit a group other than the shareholders. In addition, the means of enforcement of such duties may be located not with the shareholders, or at least not with the shareholders alone, but in some external body. In particular, where the duty is intended to benefit the market as a whole, the means of enforcement may well be placed in the hands of the regulator. There are a number of benefits to having the regulator as enforcer, including a potentially more nuanced view to remedies, since a regulator can take account of both deterrence and compensation when determining the size of any award ${ }^{57}$ As regards the latter, the UK regulator has the option of imposing a restitution order if it feels that compensation should be made available to particular individuals. ${ }^{58}$ The recent restitution order imposed against Tesco by the Financial Conduct Authority (FCA) is notable, not least because the FCA has only rarely had recourse to restitution orders in the past. Accordingly, it could hint at the start of a wider shift by the regulator towards seeking to compensate those who have suffered a loss. ${ }^{59}$ On the other hand, it remains clear that there are a number of potential downsides to actions brought by regulators; for example, a regulator has only limited resources which may limit the number of actions brought, and such a regime also raises issues of regulatory capture. ${ }^{60}$

A good illustration of a duty imposed in this context is the obligation on shareholders under the Transparency Directive to disclose their shareholdings when they cross various thresholds ${ }^{61}$ an obligation which is, in part, intended to benefit those outside the company and the market more generally. ${ }^{62}$ In line with a growing recognition that harmonisation at EU level requires a focus on supervision as well as on the rules, the Transparency Directive provides guidance to Member States as to how it should enforce the obligations set out in the Directive, while leaving to Member States the actual task of supervision. Member States are required to "lay down rules on administrative measures and sanctions applicable to breaches of the national provisions adopted in transposition of this Directive and shall take all measures necessary to ensure that they are implemented. Those administrative measures and sanctions shall be effective, proportionate and dissuasive". ${ }^{63}$ The Directive details the factors that should be taken into account when determining the appropriate sanction. ${ }^{64}$ Crucially, it also sets out the sanctions that should be available to competent authorities, and financial sanctions are one of the powers specified, alongside the issuing of a public statement of the person responsible for the breach and the nature of the breach, and an order for that person to cease the conduct constituting the breach. ${ }^{65}$ The Directive sets out different sanctions for legal entities and natural persons and in each case specifies that the competent authority should have the power to impose a sanction of a specified amount (up to EUR 2000000 for natural persons, and for legal entities EUR 10000000 or up to $5 \%$ of the total annual turnover according to the last available annual

\footnotetext{
${ }^{57}$ For further discussion see I Chiu's paper in this volume.

${ }^{58}$ Financial Services and Markets Act 2000 ('FSMA'), s 384.

${ }^{59}$ See, e.g. FCA, Final Notice, Tesco plc, Tesco Stores Ltd, 28 March 2017.

${ }^{60}$ The UK regulator has been criticised for the low level of its enforcement actions in the past (see e.g. J Coffee, "Law and the Market: The Impact of Enforcement" (2007) 156 University of Pennsylvania Law Review 229), and this is something which it has sought to address in recent years.

${ }^{61}$ Directive 2004/109/EC as amended by Directive 2013/50/EU, Art 9(1).

${ }^{62}$ Ibid, recital 18.

${ }^{63}$ Ibid, Art 28(1).

${ }^{64}$ Ibid, Art 28c.

${ }^{65}$ Ibid, Art 28b.
} 
accounts approved by the management body) or up to twice the amount of the profits gained or losses avoided because of the breach, where those can be determined, whichever is the highest.

In the UK this obligation is enforced by the FCA. ${ }^{66}$ The FCA has a range of powers available to it where a shareholder is found to have breached this duty, including the power to fine shareholders that are in breach, but also the power to apply to court for an order suspending a shareholder's voting rights. ${ }^{67}$ The UK financial regulator has exercised this power, although on only one occasion to date. In 2011 the Financial Services Authority (the predecessor of the FCA) exercised this power, issuing a fine of $£ 210,000$ to Sir Ken Morrison for failing to disclose his reduced shareholding and voting rights in Morrison Supermarkets Plc (Morrison) ${ }^{68}$ Between 2009 and 2010 he failed to notify the company on four separate occasions when his voting rights fell below the relevant thresholds imposed by the UK Disclosure and Transparency Rules. ${ }^{69}$ While he did not financially benefit from these breaches, his failure to notify Morrison of the changes to his shareholding resulted in Morrison not being in a position to update the market in accordance with the UK's disclosure rules. This resulted in the market being misled as to the ownership of voting rights in Morrison.

It is clear that financial sanctions can play an important role in this context. As the sanctions set out in the Directive make clear, there are a number of elements potentially present in the imposition of these penalties, including the removal of any advantage acquired by breaching the provisions, i.e. profits gained or losses avoided, and the need for the penalty to act as an effective deterrent. This is also clear from the FSA's decision to fine Sir Ken Morrison. The FSA applied careful and detail criteria in order to determine the size of the appropriate penalty.$^{70}$ It considered that although he had not either made a profit or avoided a loss as a result of his failure to disclose, a penalty was nevertheless required in order to provide a deterrent: there was "a clear need to impose a meaningful penalty to achieve deterrence" 71 particularly in view of his wealth and prominent position in the industry.

\section{Concluding Remarks}

In light of the foregoing analysis, and in order to judge the role and effectiveness of financial sanctions in enforcing shareholders' duties, the aims of enforcement must be considered. Very broadly, enforcement regimes tend to focus on one or both of two issues: deterrence and

\footnotetext{
${ }^{66}$ In the UK, shareholders have a statutory right to bring a claim for fraudulent misstatements in secondary market disclosures, but this claim can only be brought against the company: FSMA, s 90A. In addition, they have a right at common law to bring a claim regarding negligent misstatements in secondary market disclosures, where the purpose of the statement is to benefit the shareholders and the maker of the statement is aware that it may be relied on by that group: Caparo Industries plc v Dickman [1990] 2 AC 605. This claim remains intact after the introduction of s 90A FSMA (FSMA, Sch 10A, para $7(3)(\mathrm{a})(\mathrm{v}))$. This claim is rarely brought, and its parameters are unclear. It is theoretically possible that such a claim might arise regarding a shareholder's obligation to disclose under the Transparency Directive, but it would require a special set of circumstances.

${ }^{67}$ See the Transparency Regulations 2015 SI 1755/2015. For further discussion of this issue see [Karsten and Mette's paper in this volume].

${ }^{68}$ FSA, Final Notice, Sir Ken Morrison, 16 August 2011.

${ }^{69}$ The disclosure triggers in the UK are located in the FCA Handbook, DTR 5.1 and are more onerous than those required by Directive 2004/109/EC, as amended.

${ }^{70}$ Set out in the FCA's DEPP (Decision Procedure and Penalties Manual).

${ }^{71}$ FSA, Final Notice, Sir Ken Morrison, 16 August 2011, para 30(b). The figure agreed on was $£ 300,000$, but this was reduced by $30 \%$ in view of the fact that Sir Ken had agreed to settle at an early stage in the FSA's investigation.
} 
compensation. Deterrence aims to prevent a particular behaviour from occurring, and compensation is designed to provide a remedy to those who suffer loss or harm as a result of breach of shareholders' duties. Keeping such aims in mind, what becomes evident is that financial sanctions can be a valuable tool for shareholders (particularly when balanced against other remedies), but that the precise role such sanctions can play will vary depending on the different ways that shareholders' duties arise, as well as the wrongdoing in question. Equally, with respect to effectiveness, the actual levels of enforcement activity, and the size of any sanction imposed, will be important.

Specifically, with respect to a breach of shareholders' duties arising via contract, via the articles, or where imposed by law to moderate the intra-shareholder relationship, the award of a remedy will generally be part of a wider attempt to try and regulate the bargain as agreed between the parties. In such instances, the enforcement aims of compensation and deterrence may have less significance than simply enforcing the terms agreed by the parties, explicitly or implicitly. Equally, although financial sanctions can be a useful tool in such situations, the chapter illustrates that it can be extremely difficult for parties to succeed with such a claim. Moreover, alternatives such as granting an injunction requiring a shareholder to vote their shares in a particular way, or awarding a buy-out, may provide more pragmatic remedies. Such awards may be preferable not only for a shareholder who can, for instance, exit a company in the case of an irretrievable breakdown of relations, but also for the courts, who can bypass having to make difficult decisions for a company by basing their rulings on the premise that they are enforcing the parties' bargain.

In contrast, with respect to the enforcement of shareholders' duties via an external party such as a regulator, financial sanctions may have a more valuable role to play in practice. In this regard, one should also keep in mind the type of companies at which such sanctions will be directed. These are not small, quasi-partnership companies; rather, these are publicly traded firms in which the public's pension pots may be invested, and where duties are placed on institutional shareholders in order to benefit their underlying investors, and to benefit the market more generally. In such situations, the regulator is not attempting to manage or mediate the intra-shareholder relationship; rather the aim is to protect other stakeholders, including those that are investing in the securities markets. Accordingly, the regulator's intervention in the event of a shareholder's breach of duty can be justified here, both in order to hold those in breach accountable, and on the broader grounds of ensuring the effective and smooth functioning of the capital markets.

In light of this, the chapter demonstrates that the main function of the regulator imposing a financial sanction in such a scenario is to remove any profit obtained by the breach, and to act as a deterrent. Nonetheless, in this regard, the broader development concerning the Tesco restitution order should be kept in mind, as this could hint at the start of a move towards seeking to compensate investors who have suffered a loss. Aside from this, however, deterrence remains key. Yet, if this is a major driver behind the imposition of a financial sanction, and if there could be greater use of financial sanctions by regulators to enforce breaches of shareholders' duty going forward, then the regulator needs to fully embrace its use of such enforcement powers in practice. Further, it must ensure the penalty imposed is high enough to act as a credible deterrent and not be merely just a cost of doing business for the party in breach. Accordingly, it may be that there are limits to the impact the civil law can have in this area. Specifically, the imposition of a civil sanction may have only a limited impact on sophisticated market players, and the greater threat of criminal law enforcement, may be necessary in order to act as an effective deterrent. In this regard, the introduction of common minimum rules across the EU for the imposition of criminal sanctions in cases of market abuse may provide a valuable precedent. ${ }^{72}$

\footnotetext{
${ }^{72}$ See Ester Herlin-Karnell, 'White-Collar Crime and European Financial Crises: Getting Tough on EU Market Abuse' (2012) 37 European Law Review 481. Note that the UK and Denmark did not opt-in to
} 
the criminal sanctions regime. For the UK's approach, see e.g. $R v$ McQuoid [2009] EWCA Crim 1301 where Lord Judge CJ held that there needed to be 'an element of deterrence' in such sentences. 